\title{
Partner Choices of the Second Generation of Turkish and Former Yugoslav Origin in Switzerland: A Comparative Analysis
}

Ceren Topgül*

* University of Geneva, Institute for Demographic and Life Course Studies, CH-1211 Geneva, cerentopgul@yahoo.com.

\section{Abstracts \\ Partner Choices of the Second Generation of Turkish and Former Yugoslav Origin in Switzerland: A Comparative Analysis}

This paper explores the partner choices (exogamy, local endogamy, and transnational endogamy) of the children of Turkish and former Yugoslav immigrants, who share a comparable migration history in Switzerland, based on the Swiss TIES (The Integration of the European Second Generation) survey. The comparison of these groups puts Turkish youths' partner choice (low exogamy and relatively high transnational endogamy) into a wider perspective. Moreover, the comparison allows to disentangle ethnic and religious affiliations in order to test hypotheses on the role of ethnicity and religion in partner choices. While ethnic endogamy prevails in the two groups under study, religious boundaries are not stronger than ethnic ones. The second generations' desire for religious and educational homogamy appears to be a reason for transnational endogamy. Keywords: Partner choice, youth of Turkish origin, youth of former Yugoslav origin, comparative analysis, Switzerland

\section{Partnerwahl der zweiten Generation türkischer und exjugoslawischer Abstammung in der Schweiz: eine komparative Analyse}

Dieser Artikel untersucht das Partnerwahl-Verhalten (Exogamie, lokale und transnationale Endogamie) von Jugendlichen, deren Eltern aus der Türkei oder dem ehemaligen Jugoslawien in die Schweiz migriert sind und eine ähnliche Migrationsgeschichte haben. Die Daten der Umfrage TIES (The Integration of the European Second Generation) dienen dabei als Grundlage für die Analyse. Durch den Vergleich der zwei Migrantengruppen wird die Perspektive erweitert, sodass ein besseres Verständnis für das Verhalten von türkischen Jugendlichen bei der Partnerwahl, welches sich durch eine geringe Exogamie und eine relativ hohe transnationale Endogamie auszeichnet, erreicht wird. Des Weiteren erlaubt ein solcher Vergleich, zwischen ethnischen und religiösen Abgrenzungen zu unterscheiden. Dadurch können Hypothesen in Bezug auf die Rolle von Ethnizität und Religion bei der Partnerwahl getestet werden. Die Untersuchung zeigt, dass ethnische Endogamie in beiden untersuchten Gruppen überwiegt, jedoch ethnische Abgrenzungen nicht stärker sind als religiöse. Transnationale Endogamie wird in Verbindung gebracht mit dem Bedürfnis der zweiten Generation nach religiöser oder schulischer Homogamie.

Schlüsselwörter: Partnerwahl, Jugendliche türkischer Herkunft, Jugendliche mit Herkunft aus dem ehemaligen Jugoslawien, vergleichende Analyse, Schweiz

\section{Choix du conjoint au sein de la deuxième génération de Turcs et d'ex-Yougoslaves vivant en Suisse: une analyse comparative}

L'article analyse les choix du conjoint (exogamie, endogamie locale et transnationale) des enfants de migrants originaires de Turquie et d'ancienne Yougoslavie présentant une histoire migratoire analogue en Suisse, en se basant sur l'enquête TIES (The Integration of the European Second Generation). La comparaison entre les deux groupes permet de mettre en perspective le comportement des jeunes d'origine turque, caractérisé par une exogamie réduite et une endogamie transnationale relativement importante. Qui plus est, cette comparaison permet de démêler l'impact des appartenances ethniques et religieuses sur le choix du conjoint/ partenaire. L'endogamie ethnique prédomine dans les deux groupes étudiés et les liens religieux ne sont pas plus forts que les appartenances ethniques. La recherche d'une homogamie sur le plan éducatif et religieux semble être à l'origine de l'endogamie transnationale.

Mots-clés: Choix du conjoint, jeunes d'origine turque, jeunes originaires d'ancienne Yougoslavie, analyse comparative, Suisse 


\title{
Partner Choices of the Second Generation of Turkish and Former Yugoslav Origin in Switzerland: A Comparative Analysis ${ }^{1}$
}

\author{
Ceren Topgül*
}

Partner choice is an established field of research in immigrants' integration studies, generally with a focus on exogamy/intermarriage, as it was once thought to be the litmus test for the assimilation of new migrant groups (Alba and Nee 2003, 90). The alternative partner choice to exogamy (an out-group partner), endogamy ${ }^{2}$ can be divided into local endogamy (a co-ethnic partner living in the host country) and transnational endogamy (a co-ethnic partner from the country of origin ${ }^{3}$ ). The focus on transnational endogamy gained momentum because of researchers' concern when destination countries began to engage in restrictive admission policies; the term "marriage migration" precisely signifies this new emphasis.

Studies of the partner choices of second generation of Turkish origin in many European countries epitomize those increasing concerns, as Turkish immigration seemed to challenge assimilation expectations in Europe, mainly because of the different religious affiliation of these immigrants. Such studies were conducted in Germany (Strassburger 2004; Gonzalez-Ferrer 2006; Kalter and Schroedter 2010), France (Milewski and Hamel 2010), and Belgium (Timmerman 2006; Hartung et al. 2009). In Switzerland, however, partner choices of immigrants' offsprings have rarely been studied in general, and even fewer studies have been conducted of the partner choices of children of Turkish immigrants. The first research on this topic, based on the 2000 Swiss Census, shows that the majority of Turkish second generation had a partner with a certain amount of socialization experience in Switzerland: they tended to choose either exogamy or local endogamy, and one third of their

* University of Geneva, Institute for Demographic and Life Course Studies, CH-1211 Geneva, cerentopgul@yahoo.com.

1 I would like to thank the guest editors, as well as the anonymous reviewers for their valuable suggestions on revising this article.

2 Endogamy is the tendency of people to marry within the group (Kalmijn 1998), which is defined on the basis of ascribed characteristics, such as ethnicity, race, or religion. In this paper, the primary group definition used to study endogamy and exogamy is based on ethnicity, i.e., the parents' country of origin, not on nationality, because second generation are not necessarily nationals of the parents' country of origin.

3 Transnational marriages, in which a co-ethnic partner of the second generation comes from a country other than the parents' country of origin, constitute a very small group according to our analyses. Thus, we did not include this group in our analysis. 
unions are transnationally endogamous (Topgül 2013; Topgül 2015). Switzerland resembles France and Austria in terms of low exogamy (around 15 per cent), but is more similar to Belgium and the Netherlands in terms of the high proportion of first generation partners ${ }^{4}$ (more than 60 per cent), signalling moderate incorporation conditions and a small marriage market for co-ethnics in the country (Hamel et al. 2012).

In Switzerland, Turkish immigrants represent a significant yet numerically not very strong group; the more sizable immigration from former Yugoslavia may have attracted concerns similar to those inspired by Turkish immigrants. Moreover, knowledge about the partner choices of children of former Yugoslavian descent is lacking both in Switzerland and in Europe. This paper contributes to the literature by addressing this knowledge gap: it compares the partner choice behaviour of youth of Turkish and former Yugoslav (SSYU5 ${ }^{5}$ origin in Switzerland.

Yet, the proper value of this synchronic comparison (across origin groups) is twofold. First, the two origin groups under study share a comparable migration history in the country, as both groups arrived at the end of the 1980s and the beginning of the 1990s, either as labour migrants, asylum seekers or in the context of family reunification. These immigrant groups also have similar positions in Swiss society, in terms of their fairly recent immigration, their labor market situation, and their negative image in Switzerland (Fibbi et al. 2015). Second, more importantly, the interest of such a comparison lies with the peculiar articulation of religion and ethnicity ${ }^{6}$ in the groups under study: in the Turkish immigrant group, religion and ethnicity / origin virtually coincide with each other, whereas three different religious affiliations can be found in the former Yugoslav group; thus, religion only partially coincides with ethnicity. Therefore, comparing partner choices of the children of immigrants from these groups allows us to disentangle ethnic and religious boundaries and to analyse separately the role of religion and ethnicity on partner choices. Which symbolic boundary exerts the strongest influence?

This paper first describes the three possible partner choices - exogamy, local endogamy or transnational endogamy - of children of these immigrant origin groups, and explores the factors determining exogamy versus endogamy. Are there group differences in partner choices? Does gender matter? What are the individual characteristics and contextual factors determining endogamy versus exogamy? After exploring the issue of endogamy-exogamy, I study endogamous couples in detail

$4 \quad$ Hamel et al. (2012) do not singularise marriage migrants among first generation (Turkey-born) partners by taking into account partner's age at arrival and motive for migration.

5 SSYU stands for the "successor states of Yugoslavia." Although this is a much more appropriate way to refer to the origin of immigrants and their children, in this paper, the term "former Yugoslav origin" is also used for simplicity.

6 To designate the groups we resort to formal national denominations, which in reality encompass (and conceal) a variety of ethnic differences. Although we are aware of this shortcoming, the overall limited number of observations does not allow us to introduce more accurate distinctions. For simplicity's sake, we regard nationality and ethnicity as synonymous. 
by exploring the generational status of the partner and hence the length of his / her socialization in Switzerland: local versus transnational endogamy. Moreover, I investigate whether the circumstances of first encounter and the family influence on the second generation differ according to the migratory status of endogamous partners.

The paper further investigates religious and educational homogamy within the couples, in order to reveal the prominent characteristic(s) they share, according to each partner's migratory status. Is the degree of religious and educational homogamy different in endogamous than in exogamous couples, and in transnational endogamous couples compared to local endogamous ones in the two origin groups under study? It is of particular interest to examine religious versus ethnic boundaries, both of which were proven to play a role in the partner choices of children of immigrants (Kalmijn 1998; van Tubergen and Maas 2007; Lucassen and Laarman 2009). Taking into account second generation's religion in the analysis of their marriages and contrasting it with national and ethnic origin is the true innovative contribution of this article to the literature.

Data from the Swiss TIES (The Integration of the European Second Generation) survey is the basis for my analyses. The TIES survey generated (representative) data on second generation of Turkish and SSYU origin, who were born in Switzerland to parent(s) born abroad. The respondents for the TIES project were between the ages of 18 and 35. The survey provides a large set of comprehensive information regarding both second generation of Turkish origin $(\mathrm{N}=449)$ and former Yugoslav origin $(\mathrm{N}=431)$ and their partners in two urban agglomerations of Switzerland, in Zurich and Basel.

These metropolitan areas, both in the German-speaking part of Switzerland, were selected for TIES because they present the highest numbers of Swiss-born residents of Turkish and SSYU origin, according to the 2000 Swiss Census. Both cities are important centres of Swiss economic activity.

For the Turkish origin population, Basel features more ethnic and religious pluralism, as it hosts more Kurds and Alevi Muslims, as well as non-religious respondents, than is the case in Zurich. For the much more diversified SSYU origin population, there is less of a polarisation between the two agglomerations; however, Zurich presents a certain concentration of Muslim families and Kosovars. In both agglomerations, Turkish and SSYU origin respondents are found to be mainly children of guest workers.

In this section, I briefly describe second generation's union formation experience. After studying ethnic endogamy-exogamy of Turkish and SSYU youth, and investigating the factors behind these choices (in Section 2), I detail my analyses by studying religious endogamy (Section 3) and educational homogamy (Section 4) with respect to ethnic endogamy-exogamy and partners' migratory status. 


\subsection{Current union of second generation youth}

To understand the partner choice pattern of the population under study, I will briefly describe their union formation experiences, including the conditions under which partners met.

Turkish and SSYU migratory flows are fairly recent; therefore, TIES respondents who were born in Switzerland represent the very first second generation. Thus, in the survey, a majority of native born second generation of Turkish and SSYU origin are under the age of 25. Around one fifth of youth of Turkish origin are under age 20, while 36 per cent of Turkish and SSYU second generation are in their early twenties. Because of their young age, the majority of them are single. Among youth of both origins who are currently in a union, marriage is the preferred type of union.

Children of Turkish and SSYU immigrants display similar family formation behaviours in various respects, such as the timing of their unions: at least two thirds of youth with migratory backgrounds marry before age 25. Yet, cohabitation of unmarried partners is more common among SSYU youth than it is among Turkish second generation. Family members somehow influence the decisions of children in both origin groups, generally through the indirect form of framing meeting circumstances; one woman in five, however, is exposed to direct interference in her choice both in Turkish and in SSYU second generation. Youth of Turkish origin rely on family and their country of origin to meet a partner more than SSYU second generation do.

\section{Partner choice of second generation: Partner's origin and migratory status}

This section describes and compares the partner choice behaviour of Turkish and SSYU origin youth, on the basis of not only ethnic and national origin, but also the migratory status of the partner. The analyses include both married and cohabitating couples, unless stated otherwise.

Exogamous couples, whether cohabitating or married, are to be found among SSYU origin youth (29 per cent) and, to a smaller degree, among Turkish origin youth (16 per cent) (Table 1). Exogamy declines drastically in the case of marriage (six per cent of Turkish origin and 12 per cent of SSYU origin youth - not shown in the table).

A significant group difference is observed between women in the two origin groups (Table 1). Exogamy of SSYU origin women (21 per cent) is three times higher than exogamy of Turkish origin women (seven per cent), which fades away if we only take marriages into account. Thus, the difference can be explained by higher cohabitation in the former group.

Women's lower tendency, compared to men, to marry out of the ethnic group is observed in both origin groups; yet, the gender difference is not significant for 
Table $1 \quad$ Partner's migratory status by origin group and gender

\begin{tabular}{lrrrrrrr}
\hline Migratory status of partner & \multicolumn{3}{c}{ Turkish origin } & \multicolumn{3}{c}{ SSYU origin } \\
& Men & Women & Total & Men & Women & Total \\
\hline Exogamy & $22.4 \%$ & $7.0 \%$ & $15.7 \%$ & $37.3 \%$ & $21.4 \%$ & $28.7 \%$ \\
Local endogamy & $46.6 \%$ & $56.1 \%$ & $50.4 \%$ & $43.3 \%$ & $52.4 \%$ & $48.7 \%$ \\
Transnational endogamy & $31.0 \%$ & $36.8 \%$ & $33.9 \%$ & $19.4 \%$ & $26.2 \%$ & $22.7 \%$ \\
N & 59 & 64 & 123 & 55 & 78 & 133 \\
\hline
\end{tabular}

Notes: SSYU = Successor States of Yugoslavia (Bosnia, Kosovo, Croatia, Macedonia, Montenegro, Serbia, Slovenia). Source: Swiss TIES Survey 2007-2008.

SSYU youth. Among exogamous unions, we observe that partners of SSYU women are almost always Swiss, whereas approximately 50 per cent of partners of SSYU men are Swiss, while the others come from a variety of other countries (not shown in the table). Men of Turkish origin in exogamous relationships more often have partners of other origin (14 per cent versus nine per cent who are of Swiss origin), which raises the question of whether or not these couples are religiously endogamous. Yet, further investigation does not prove ethnic exogamy on the basis of religious homogamy. We will return to this point later.

At least seven out of ten respondents in both origin groups have partners with the same ethnic background, yet the trend is more pronounced among Turkish youth (84 per cent) than it is among SSYU second generation $(71 \text { per cent })^{7}$. The prevalence of marriages involving co-ethnic partners from the country of origin is significantly higher for youth of Turkish origin compared to SSYU youth (34 versus 23 per cent). Yet, transnational endogamy accounts for less than 50 per cent of endogamous marriages in both origin groups. It concerns women of Turkish origin (37 per cent) somewhat more than men of the same origin (31 per cent) and much more than women of SSYU origin (26 per cent) (Table 1).

High prevalence of ethnic endogamy is not specific to the groups under study, nor is it specific for the Swiss context, according to various studies in many European countries. ${ }^{8}$ Group differences in Switzerland stem from lower exogamy and

$7 \quad$ Within the SSYU group, if we look at the father's country of origin according to the successor states of Yugoslavia (Bosnia, Kosovo, Croatia, Macedonia, Montenegro, Serbia, Slovenia), we see that young people's partner choices do not very often cross these national boundaries: some 70 percent of all endogamous unions are within these boundaries.

8 Gonzalez-Ferrer (2006) shows high ethnic endogamy rates among immigrants of Italian origin (82 per cent), Spanish origin (82 per cent), Greek origin (88 per cent) and former Yugoslav origin (75 per cent) in Germany; just as Lievens (1999) observed among Moroccan young adults with migratory background (86 per cent) in Belgium. 
Figure $1 \quad$ Turkish and SSYU second generation's endogamous and exogamous marriages versus their partners' length of socialization in Switzerland by origin group

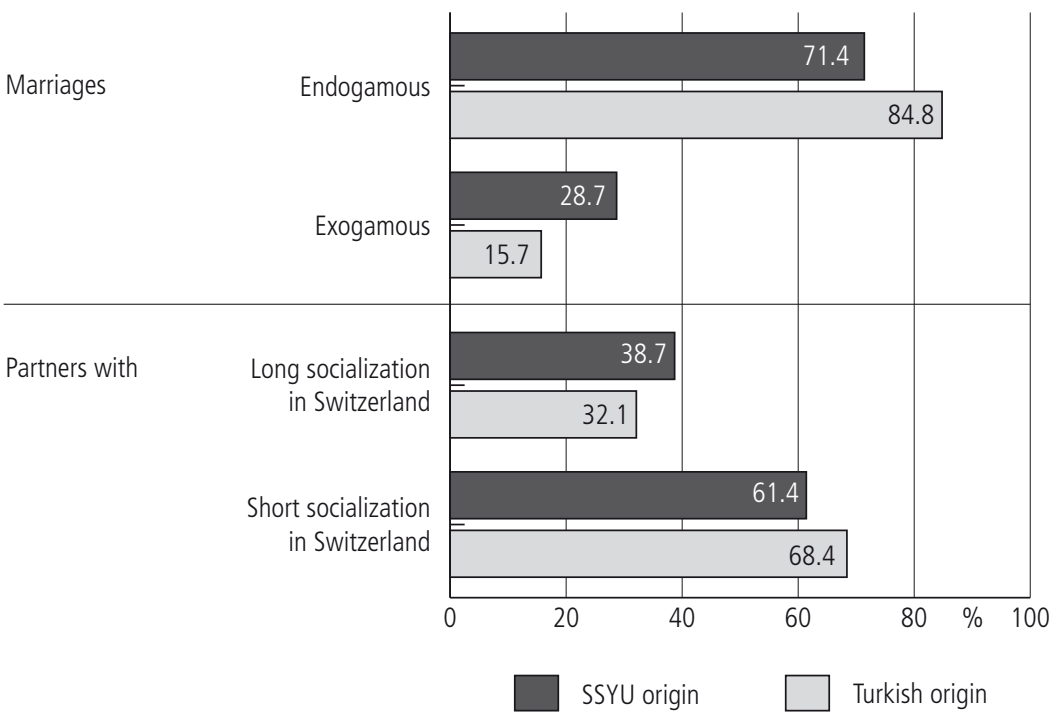

Notes: Length of socialization is grouped as long (experience of Swiss or other origin and second generation partner) or short (experience of first generation partners). SSYU = Successor states of Yugoslavia (Bosnia, Kosovo, Croatia, Macedonia, Montenegro, Serbia, Slovenia).

Source: Swiss TIES Survey 2007-2008.

higher transnational endogamy of Turkish origin youth compared to SSYU second generation, which is in line with Gonzalez-Ferrer's (2006) findings ${ }^{9}$ in Germany.

One category, the youth of Turkish origin, is rather specific in terms of high transnational endogamy. Transnational marriages are "typical" for Turkish communities in different Western European countries (Gonzalez-Ferrer 2006). Transnational marriages of children of immigrants from Turkey and Pakistan, in Denmark, constituted half of their unions in 2000 (Çelikaksoy 2004). Unlike Turkish and Pakistani second generation, descendants of two other Muslim immigrant groups, Algerians in France and Moroccans in Belgium, less often enter transnational marriages (Milewski and Hamel 2010). Youth of former Yugoslav origin resemble this latter group.

9 Gonzalez-Ferrer (2006) does not make any distinction between the first, middle (immigrated at age between 6 and 15) and second generation. 
Based on the ethnic/ national origin of partners, endogamy is the main feature of marriages of children of immigrants. However, one third of marriages among both Turkish and SSYU respondents involve a partner who is already acculturated to the local immigration society (Figure 1).

The proportion of endogamous couples is significantly higher among younger SSYU respondents who are under 25 (93 per cent) compared to those aged 25 and older (33 per cent), while age difference is not significant among Turkish youth (not shown in the table). Neither is there an agglomeration difference. The marriage market for Turkish origin youth appears quite similar in the two agglomerations under study, whereas distinctive features appear for SSYU origin youth, for whom exogamy is two times higher (20 versus 41 per cent) and local endogamy is lower (56 versus 38 per cent) in Basel compared to Zurich. The lower concentration of Muslim families in Basel than in Zurich might explain SSYU youth's higher exogamy in Basel. Heterogeneity of the Turkish community does not seem to influence partner choice of the youth of Turkish origin who live in Basel.

\subsection{Circumstances of the first meeting and family influence on partner choice}

Analysing the mechanisms behind the process of choosing a particular type of partner over another, here I study each couple's first encounter and the family influence on partner choice according to the migratory status of the partner of Turkish and SSYU origin youth, by distinguishing family framed (such as during family celebrations) and individually framed (such as at school or work environment) encounters.

According to Table 2, individually framed encounters are systematically higher among local and transnational endogamous unions of SSYU second generation (78 per cent and 54 per cent respectively) compared to youth of Turkish origin ( 55 per cent and 37 per cent respectively). The group difference is statistically significant in the case of local endogamy. Encounters with co-ethnic partners in Switzerland are twice as likely to be family framed among youth of Turkish origin (24 versus 11 per cent) than among SSYU youth. The two origin groups rely equally on the family in cases of transnational partner choices.

The chance of individually framed encounters are higher for partners with longer socialization experience in Switzerland: 69 per cent of the youth of Turkish origin and 93 per cent of SSYU youth met with a second generation partner on social occasions, while only 49 per cent of the youth of Turkish origin and 74 per cent of SSYU youth met first generation partners under this condition (not shown in the table). Family framing prevails in encounters, whatever the Turkish youth's partner choice is (around one fifth in each type of partner).

A similar pattern of family influence is observed in both origin groups: some 13 to 14 per cent of the second generation are either encouraged or discouraged by family members in their partner choices (not shown in the table). Family involvement does not significantly vary according to the migratory status of the partner, 
Circumstances of the first meeting according to partner's migratory status by origin group

\begin{tabular}{lcccccccc}
\hline & \multicolumn{2}{c}{ Exogamy } & \multicolumn{2}{c}{ Local endogamy } & \multicolumn{2}{c}{ Transnational } & \multicolumn{2}{c}{ Total } \\
& \multicolumn{1}{c}{$\begin{array}{c}\text { Turkish } \\
\text { origin }\end{array}$} & $\begin{array}{r}\text { SSYU } \\
\text { origin }\end{array}$ & $\begin{array}{r}\text { Turkish } \\
\text { origin }\end{array}$ & $\begin{array}{r}\text { SSYU } \\
\text { origin }\end{array}$ & $\begin{array}{r}\text { Turkish } \\
\text { origin }\end{array}$ & $\begin{array}{r}\text { SSYU } \\
\text { origin }\end{array}$ & $\begin{array}{r}\text { Turkish } \\
\text { origin }\end{array}$ & $\begin{array}{r}\text { SSYU } \\
\text { origin }\end{array}$ \\
\hline $\begin{array}{l}\text { Individually framed } \\
\text { Holiday in parents }\end{array}$ & $93.8 \%$ & $85.4 \%$ & $55.2 \%$ & $78.1 \%$ & $36.8 \%$ & $54.3 \%$ & $53.5 \%$ & $74.7 \%$ \\
country & & & $13.8 \%$ & $8.2 \%$ & $36.8 \%$ & $20.0 \%$ & $20.2 \%$ & $8.7 \%$ \\
Family framed & & & $24.1 \%$ & $11.0 \%$ & $23.7 \%$ & $20.0 \%$ & $21.1 \%$ & $10.0 \%$ \\
Other & $6.3 \%$ & $14.6 \%$ & $6.9 \%$ & $2.7 \%$ & $2.6 \%$ & $5.7 \%$ & $5.3 \%$ & $6.7 \%$ \\
$\mathrm{~N}$ & $(16)$ & 34 & 63 & 65 & 42 & 32 & 121 & 131 \\
\hline
\end{tabular}

Notes: Individually framed encounters include friend circle, school or work environment, associations, social clubs, political parties, public spaces, night clubs, and during holiday somewhere other than Turkey. Family framed encounters include parents' introduction of the partners, family celebrations and family network.

Source: Swiss TIES Survey 2007-2008.

contrary to Milewski and Hamel's (2010) finding in France, where Milewski and Hamel observed higher family involvement in the case of Turkish youth's transnational marriages. Unfortunately, the low number of observations does not allow any further analyses.

\subsection{Modeling exogamous partner choice of second generation}

Descriptive bivariate analyses have mapped so far the marriage behaviour of second generation of Turkish and SSYU descent. Here I analysed the determinants of exogamous partner choices in order to understand the relative importance of individual and group characteristics, such as education level, ethnicity, and religion. The following variables are used in the logistic regression model: origin group (Turkish origin versus SSYU origin [ref.]); sex (men [ref.] versus women); agglomerations (Zurich versus Basel [ref.]); age category (ages under 25 and ages 25 and over [ref.]); educational level (compulsory education, upper secondary education [ref.], tertiary education, and other education); elder siblings (having [an] elder sibling [ref.] or not); Swiss close friends while growing up (having at least one Swiss close friend or not [ref.]); religion today (Muslim or Christian versus having no affiliation [ref.]).

The origin group does affect exogamous partner choice. They youth of Turkish origin are less likely to enter exogamous unions (odds ratio: 0.4 ) compared to the youth of SSYU origin, which confirms the descriptive analysis. Moreover, when religion is included in the model, the impact of ethnicity does not fade away. 
Women's lower likelihood of making exogamous partner choices compared to men is confirmed for the youth of Turkish and SSYU origin in Switzerland (odds ratio: 0.4 ). The place where second generation is living, Zurich versus Basel, also has an impact on partner choice: in the former, the likelihood of exogamy versus endogamy is lower (odds ratio: 0.3) than in the latter (reference category). Because the interaction term (origin*agglomeration) that we added to the model is significant, the impact of agglomeration on the propensity of youth of Turkish and SSYU origin to choose an out-group partner differs significantly. Moreover, when we add this term, being of Turkish descent has a larger negative effect on exogamy (odds ratio: 0.2 ).

Education influences the partner choices of second generation: lack of postcompulsory education significantly decreases the likelihood of exogamy (odds ratio: 0.2 ), yet achieving tertiary education has no impact on the choice. On the other hand, having at least one close Swiss friend during compulsory education is not found to have a significant impact; moreover, contrary to our expectations ${ }^{10}$, having an elder sibling is not found to affect exogamy significantly.

As expected, religion is found to be an important factor in explaining exogamous partner choice of second generation. Youth who are affiliated to a religion - Islam or Christianity - are less likely to enter ethnic exogamous unions compared to those who are not affiliated. Yet, the influence is significant only for Muslims (odds ratio: 0.3 ).

Predicted probabilities of exogamy at mean are presented in Figure 2 in order to help us interpret the relations in the model.

The probability of exogamy at the mean is 16.5 per cent for youth with the migratory background under study. It is higher for SSYU origin youth compared to those of Turkish origin, 20.6 and 12.2 per cent respectively. Predicted probabilities confirm a lower chance of exogamy for women (10 per cent) compared to men (27.6 per cent). Educational level is found to positively affect exogamy. The probability of exogamy at the mean is 3.5 per cent for youth with compulsory education, but 23.2 per cent for those who have achieved a tertiary level. The difference according to city of residence, which is observed in the logistic regression results, can now be better understood with the help of predicted probabilities of the interaction term (origin*agglomeration): the probability of exogamy of the youth of Turkish origin is higher in Basel (17.2 per cent) compared to Zurich (8.8 per cent), which confirms our expectation based on the heterogeneity of the Turkish community in

10 Analysing the qualitative interviews that I carried out with young people of Turkish origin in Switzerland, I observed a variation in the types of unions and partner choices among siblings within a single family (Topgül 2015). This variation points out a transformation in young people's attitudes and behaviours - especially of those born in Switzerland. Younger siblings more often chose exogamous unions as well as cohabitation. This transformation was also observed among children of immigrants in other contexts, such as among Algerian families in France (see Sayad 1979). 
Figure 2 The impacts of the predictors on exogamy probability of second generation

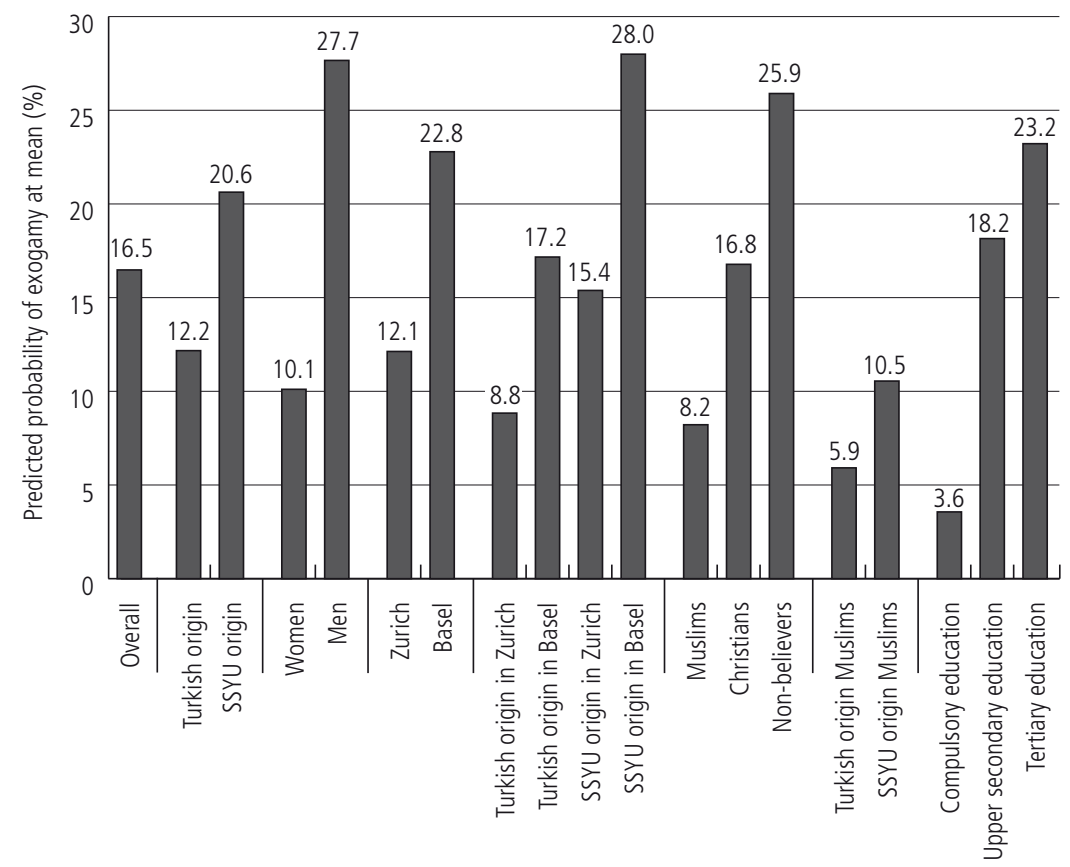

Notes: SSYU = Successor states of Yugoslavia (Bosnia, Kosovo, Croatia, Macedonia, Montenegro, Serbia, Slovenia). Source: TIES Survey 2007-2008.

the former. Moreover, we observe the same pattern for SSYU origin youth (28 per cent in Basel versus 15.4 per cent in Zurich). Thus, group boundaries seem to be stronger in Zurich.

The impact of the respondents' current religion varies with the size of religious groups in the marriage market in Switzerland. Thus, the probability of exogamy is two times higher among Christian (16.8 per cent) compared to Muslim (8.2 per cent) second generation. At the same time, ethnicity plays a role within the Muslim group: the probability of exogamy among muslims of Turkish origin (5.9 per cent) is lower than the probability for Muslims of SSYU origin (10.6 per cent). 


\section{Ethnic and/or religious boundaries}

Partner choice is a crucial topic in order to analyse how children of immigrants live the ethnic and religious boundaries in their everyday lives (Wimmer 2008). Their choices reveal the role that they play in giving salience to previous group boundaries, or designing new profiles.

Although endogamy is generally defined by national origin, religion can also be the common denominator for defining social groups that are homogenous in terms of social norms regarding, for instance, marriage and family. As such, religion may influence partner choices, either through the socialization process or through sanctions against exogamy. Religion might also influence partner preferences: people generally prefer to marry someone culturally similar (Kalmijn 1998) and religion is a core element of culture, since it is associated with cultural values, beliefs, and practices (Van Tubergen and Maas 2007).

In the Netherlands, immigrants affiliated to a non-Christian religion ${ }^{11}$ are found to be more likely to marry co-ethnics, which is explained by fewer opportunities to meet partners who have a similar religion among the group of natives (Van Tubergen and Maas 2007). Ethnic endogamy is most frequent in the Hindu and Muslim communities of Western Europe. Muslim migrants seldom marry non-Muslims (Lucassen and Laarman 2009).

For my analyses concerning religious endogamy-exogamy, I defined religious belonging as the individual's personal present religious affiliation, which may not always correspond to his or her religious upbringing (Fibbi et al. 2015). According to this definition, 42 per cent of the youth of Turkish origin, some of whom were raised as Muslims, declare no religious affiliation. Moreover, looking at those who exhibit a religious affiliation in the two origin groups, we observe that almost all religious respondents of Turkish origin are Muslims (primarily Sunnis and Alevis), while a majority of religious respondents of SSYU origin are Christian (mainly Orthodox and Catholic) and 23 per cent are Muslims.

Among the youth of Turkish origin, Muslim-Muslim couples constitute 49 per cent of all unions (marriage and cohabitation). Meanwhile in 27 per cent of the unions we observe a Muslim partner and a non-religious one, in 14 per cent we find two non-religious partners, and five per cent of couples include one Muslim and one Christian partner (not shown in the table). Among SSYU respondents, homogeneous Christian-Christian couples dominate (40 per cent) along with homogeneous Muslim-Muslim couples (15 per cent) and homogeneous non-religious couples (14 per cent). Twenty three per cent of the couples include one non-religious partner and one religious one, whether Muslim or Christian.

Considering all respondents in unions, ethnic and religious group boundaries have similar impacts on the partner choices of SSYU youth (religious and ethnic

11 Any religion except Christianity. 
Table 3

Ethnic or religious endogamy-exogamy in all unions by origin group and gender

\begin{tabular}{llccccc}
\hline & \multicolumn{3}{c}{ Turkish origin } & & & SSYU origin \\
& Men & Women & Total & Men & Women & Total \\
\hline Ethnic & & & & & & \\
Endogamy & $77.6 \%$ & $93.1 \%$ & $84.6 \%$ & $62.7 \%$ & $78.8 \%$ & $71.9 \%$ \\
Exogamy & $22.4 \%$ & $6.9 \%$ & $15.4 \%$ & $37.3 \%$ & $21.2 \%$ & $28.1 \%$ \\
$N$ & 59 & 66 & 125 & 55 & 80 & 135 \\
Religious & & & & & & \\
Endogamy & $58.6 \%$ & $69.0 \%$ & $63.8 \%$ & $72.1 \%$ & $60.0 \%$ & $65.4 \%$ \\
Exogamy & $41.4 \%$ & $31.0 \%$ & $36.2 \%$ & $27.9 \%$ & $40.0 \%$ & $34.6 \%$ \\
N & 59 & 66 & 125 & 55 & 80 & 135 \\
\hline
\end{tabular}

Notes: SSYU = Successor states of Yugoslavia (Bosnia, Kosovo, Croatia, Macedonia, Montenegro, Serbia, Slovenia). Source: Swiss TIES Survey 2007-2008.

endogamy in one third of the couples) while ethnic boundaries are stronger than religious ones among the Turkish second generation ( 85 per cent of ethnic endogamy versus 64 per cent of religious endogamy) (Table 3). This group difference fades away if we take into account religious youth: for Turkish and SSYU youth affiliated to a religion, ethnic and religious boundaries have the same impact (around 80 per cent of youth engage in ethnic and religious endogamy among religious youth, whatever their origin).

Kennedy (1944 and 1952) studied the importance of ethnic and / or religious boundaries in the partner choice of second generation in the U.S. In the theoretical strand of assimilation studies concerning second generation, during the aftermath of the Second World War, Kennedy observed that marriage across national boundaries was taking place within population pools inside religious boundaries: Catholicism, Protestantism, and Judaism. Therefore, she speaks about a "triple melting pot." According to her argument, religious barriers to partnership stand higher than ethnic barriers, so it is easier to cross ethnic boundaries than religious ones. In that case, we expect "religious endogamy and ethnic exogamy" to be an intermediate step between "ethnic + religious" endogamy on one side and "ethnic + religious" exogamy on the other side [Hypothesis 1].

The Kennedy hypothesis - Hypothesis 1 - is not confirmed for youth of either immigrant origins in Switzerland, for whom ethnic boundaries still maintain their importance (Table 4). Yet, among SSYU men, religion is a melting pot to a larger extent: in one of five marriages of SSYU men, the couple shares religious affiliation rather than ethnic origin. The proportion of this group is only five per cent among Turkish origin men. About one fourth of the unions of men and women of Turkish 
Table 4

Combined ethnic and religious endogamy-exogamy by origin group and gender

\begin{tabular}{lrrrrrrr}
\hline & \multicolumn{3}{c}{ Turkish origin } & \multicolumn{3}{c}{ SSYU origin } \\
& Men & Women & Total & Men & Women & Total \\
\hline Ethnic and religious endogamy & $51.7 \%$ & $67.2 \%$ & $60.0 \%$ & $50.7 \%$ & $51.8 \%$ & $51.3 \%$ \\
Ethnic endogamy \& religious exogamy & $25.9 \%$ & $24.1 \%$ & $25.2 \%$ & $11.9 \%$ & $27.7 \%$ & $20.4 \%$ \\
Ethnic exogamy \& religious endogamy & $5.2 \%$ & $1.7 \%$ & $3.5 \%$ & $20.9 \%$ & $8.4 \%$ & $14.5 \%$ \\
Ethnic and religious exogamy & $17.2 \%$ & $6.9 \%$ & $11.3 \%$ & $16.4 \%$ & $12.0 \%$ & $13.8 \%$ \\
N & \multicolumn{1}{c}{59} & 65 & 124 & 55 & 79 & 134 \\
\hline
\end{tabular}

Notes: SSYU = Successor states of Yugoslavia (Bosnia, Kosovo, Croatia, Macedonia, Montenegro, Serbia, Slovenia). Source: Swiss TIES Survey 2007-2008.

origin and SSYU women is "ethnic endogamy and religious exogamy," which can be explained by the composition of religious diversity in the couple: a large share of non-religious partners ${ }^{12}$ of the Muslim Turkish second generation (27 per cent of all unions) and a large share of non-religious SSYU youth ${ }^{13}$ and a religious partner (25 per cent). These religious non-affiliations do reflect the current situation of second generation or partners; thus, couples are not sharing a current religious affiliation in spite of their similar religious upbringing.

Another point to study in this section is the interaction opportunities in Switzerland with respect to the religious affiliation of young adults. Children of Turkish and SSYU descent are the first social group who introduces a previously unknown religious segmentation into the Swiss marriage market. Thus, it is important to explore the link between religious endogamy and the type of partner, or, to be precise, to find out whether transnational endogamy is due to desired religious endogamy. We, therefore, expect partners from the country of origin to be equally or more often affiliated to a religion, compared to other types of partners of second generation [Hypothesis 2]. Moreover, we expect these partners to be more often Muslims, as the marriage market for such a partner is small in Switzerland [Hypothesis 3]. If these hypotheses hold, transnational marriages can be linked to the desire for religious endogamy, which explains why second generations turn to their country of origin to look for a partner.

Religious affiliation of transnational partners is almost a rule among Turkish youth (92 per cent), which can be explained by higher religiosity in Turkey. Partners of SSYU youth are religiously affiliated to the same extent (86 per cent) in

12 We do not have information on the religious upbringing of the partner.

13 Half of these non-religious SSYU youth share a religious background (upbringing) with their partners (according to the partner's religion today). 
Table 5

Partner's migratory status by respondent's religion and origin group

\begin{tabular}{lrrrrr}
\hline Partner's migratory status & \multicolumn{2}{c}{ No religion } & \multicolumn{2}{c}{ Respondent's religion } \\
& Turkish origin & SSYU origin & SSYU origin & Turkish origin & SSYU origin \\
\hline Exogamy & $17.0 \%$ & $38.8 \%$ & $23.4 \%$ & $11.9 \%$ & \\
Local endogamy & $57.4 \%$ & $40.3 \%$ & $53.1 \%$ & $47.8 \%$ & $62.5 \%$ \\
Transnational endogamy & $25.5 \%$ & $20.9 \%$ & $23.4 \%$ & $40.3 \%$ & $37.5 \%$ \\
N & 49 & 59 & 56 & 73 & 16 \\
\hline
\end{tabular}

Notes: SSYU = Successor states of Yugoslavia (Bosnia, Kosovo, Croatia, Macedonia, Montenegro, Serbia, Slovenia). Source: Swiss TIES Survey 2007-2008.

the case of endogamy - be it local or transnational. Similarly high proportions of religiously affiliated persons are observed among first-generation partners, whose religious affiliation is significantly higher than that of second-generation partners (90 versus 71 per cent) (not shown in the table). Hence, it can be concluded that the desired religious endogamy is achieved either through transnational endogamy (both for Turkish and SSYU origin youth) or through local endogamy (for SSYU youth). Thus, Hypothesis 2 is confirmed only for Turkish origin youth, whereas partners of SSYU youth, in locally and transnationally endogamous unions, are equally affiliated to a religion.

On average, one third of the Muslims of both Turkish and SSYU origin have transnational marriages. We may wonder whether the choice of a partner from the country of origin concerns only Muslims or also other religiously affiliated respondents. Table 5 shows that this choice is more frequent among Muslims than among Christians or non-religiously affiliated respondents. Whatever their origin, Muslim youth rely more on the marriage market in their country of origin. Thus, Hypothesis 3 is confirmed for both origin groups.

Religious denominations ${ }^{14}$ are expected to have an impact on the type of partner chosen, independent of the ethnic origin [Hypothesis 4], as the literature provides evidence on the existence of boundaries in line with certain denominations (such as being Sunni - Geaves 2003; Erdem 2009). My analysis confirms Hypothesis 4, and thus the role of denominations in partner choices of children of immigrants in Switzerland. Religious endogamy with respect to the denomination of both partners is a distinct feature of Sunni Muslims (90 per cent - not shown in the table) and, to a smaller extent, of Catholic and Orthodox Christians: more than

14 In order to study religious denominations, youth with migratory background (youth of Turkish and SSYU origin) are regarded as a single group. 
one third of their unions is between partners from the same denomination, whereas Alevis have the highest religious exogamy (half of their unions). Moreover, Alevis as well as Catholic and Orthodox Christians more often cross ethnic boundaries (in one fourth of their unions) compared to Sunni Muslims (only one out of ten unions). Yet, Alevis and Sunnis resemble each other in making transnational partner choices: one in three marriages is transnational. This is not surprising, given that Muslim potential partners, either Sunni or Alevi, are rare in Switzerland. It is important to note that religious endogamy with respect to denominations is not specific to youth of immigrant origin: it was found to be important among Swiss couples (either Catholic or Protestant) and concerned almost half of the marriages in 1998 (FSO 2009).

\section{Ethnic and/or educational homogamy}

Arguments have been made in the literature that similarity of educational level in a couple is a key factor defining partner choice. My analyses from the 2000 Swiss Census show that educational homogamy concerns two thirds of the unions of Turkish second generation, the proportion being higher in the case of local endogamy than in transnational marriages. Swiss TIES 2007 results, however, reveal a lower share: fewer than half ( 43 per cent) of Turkish couples were found to have educational homogamy (Topgül 2013).

My interest here is to compare the prevalence of educational homogamy in two origin groups and to test the variability of homogamy according to structural position; according to Girard (1964) and Gokalp (1978), homogamy is stronger in working class milieus and weaker among the middle class. Thus, we expected a high share of educational homogamy among youth of Turkish and SSYU origin [Hypothesis 5]. Moreover, I also decided to test whether higher homogamy in the case of transnational unions, which is observed, for instance, in the Netherlands (Hooghiemstra 2003; Lucassen and Laarman 2009), would be confirmed in Switzerland for the children of immigrants. Second generation may choose transnational marriages due to their wish for an educated or better-educated partner, in which case we expected to find high homogamy in the case of transnational endogamy [Hypothesis 6].

According to Table 6, educational homogamy is significantly higher among couples comprised of SSYU youth compared to Turkish youth: in more than two thirds of the SSYU couples, partners have the same educational levels, which is a higher share than among Turkish couples (43 per cent). This finding does not seem coherent with the variability of homogamy according to structural position, so that Hypothesis 5 cannot be confirmed. A number of factors may account for this outcome: reduced numbers of observations, or the fact that some respondents are still in school. 
Table 6 Couples' educational level by origin group and type of partner

\begin{tabular}{lrcccccc}
\hline & & \multicolumn{2}{c}{ Turkish origin } & & \multicolumn{3}{c}{ SSYU origin } \\
& endogal & $\begin{array}{c}\text { Transnational } \\
\text { endogamy }\end{array}$ & Total & $\begin{array}{c}\text { Local } \\
\text { endogamsnational } \\
\text { endogamy }\end{array}$ & Total \\
\hline Same level of education & $42.6 \%$ & $30.0 \%$ & $43.2 \%$ & $69.8 \%$ & $55.2 \%$ & $67.2 \%$ \\
Higher than partner & $29.8 \%$ & $20.0 \%$ & $22.7 \%$ & $14.3 \%$ & $13.8 \%$ & $11.5 \%$ \\
Lower than partner & $27.7 \%$ & $50.0 \%$ & $34.1 \%$ & $15.9 \%$ & $31.0 \%$ & $21.3 \%$ \\
N & 52 & 32 & 96 & 56 & 27 & 108 \\
\hline
\end{tabular}

Notes: SSYU = Successor states of Yugoslavia (Bosnia, Kosovo, Croatia, Macedonia, Montenegro, Serbia, Slovenia). Source: Swiss TIES Survey 2007-2008.

Moreover, we observe a link between homogamy and the partners' migratory status: the education level of second generation is more often lower than the level of their partners in the case of transnational endogamy compared to local endogamy in both groups (50 versus 28 per cent for Turkish youth and 31 versus 16 per cent for SSYU youth); the difference is significant only for Turkish youth (Table 6). Thus, youth of Turkish and SSYU origin seem to rely on the marriage market in the country of origin due to their wish for an educated partner. Hypothesis 6 is confirmed for youth of both Turkish and SSYU origin.

\section{Conclusion}

Analyses presented in this paper portray and expand our knowledge about the partner choices of children of immigrants from Turkey and the successor states of Yugoslavia in Switzerland, and allow us to distinguish the role of religion and ethnicity on partner choices of youth with a migratory background.

\subsection{Partner choices: Exogamy, local and transnational endogamy}

Ethnic endogamy is the main partner choice pattern of youth of both Turkish and former Yugoslav origin in Switzerland. Youth of Turkish origin have lower intermarriage and higher transnational partner choice rates compared to the SSYU second generation. This is in line with some empirical findings in other European countries. Yet, SSYU youth have a higher probability of exogamy. Religion influences young people's likelihood of exogamous partner choices, yet its impact varies according to the relative importance of a particular religious group in the Swiss marriage market. Christian youth have a higher likelihood of crossing ethnic boundaries and have exogamous unions. The Muslim group does not display the same preferences, as 
exogamy is more likely among SSYU Muslims than Turkish Muslims. Moreover, exogamy is found to be associated with young people's place of residence: exogamous partner choice is more likely for youth of Turkish origin in Basel, where the Turkish community is more heterogeneous, and is less likely for SSYU youth in Zurich, where Muslim families present a certain concentration. Thus, the structure of the community has an important effect on exogamy levels. On the one hand, social control variables, such as religion and the community's structure, and, on the other hand, social mobility variables, such as educational attainment, have an impact on exogamous partner choice. Yet, one should not rush to link exogamy (or transnational endogamy) and success (or failure) of an individual's "integration" into the host society. I agree with the argument of Song (2009, 341), who questions these putative links and argues that

while intermarriage may be said to herald a form of structural assimilation in terms of one's status and formal inclusion in certain families and social networks and institutions, we cannot assume that minority individuals who have intermarried necessarily feel welcomed, or that they "belong", in many mainstream settings. Nor should we assume that an interracial partnership is automatically devoid of prejudice or racism within the couple relationship or the wider family network (or indeed the wider society).

Choosing intermarriage does not necessarily mean that one feels a sense of belonging to the resident country. Thus, exploring the phenomenon in relation to other types of partner choices made by young adults with migratory background, i. e. exogamy and local endogamy, is crucial. Yet, the limited number of observations made further analyses of transnational marriages impossible. Transnational partner choice can still be linked to second generations' desire for religious endogamy or educational homogamy.

\subsection{Distinguishing ethnic and religious boundaries}

In spite of its relatively small sample, Swiss TIES data allowed an interesting exploration of ethnic and religious boundaries in the process of partner choice. In this paper, young people's current affiliation to a religion could be studied as an individual factor - an indicator of personal social reality. As such, religion plays an important role in the partner choices of the young adults under study: religious endogamy concerns more than half of second generation couples, both of Turkish and SSYU descent. However, contrary to some previous findings (Kennedy 1952), religious boundaries are not stronger than ethnic ones. We observe that ethnic endogamy prevails and that ethnic or language boundaries still maintain their importance in both groups under study. Thus, religion does not appear to be a melting pot for second generation youth in Switzerland. 
However, second generation's affiliation to a religion still decreases the probability of ethnic exogamy, which is more pronounced among Muslims than Christians. Moreover, Muslim youth of both origins more often choose a partner from the country of origin, as they are one of the first social groups who brought previously unknown religions to Switzerland, and the marriage market, especially for SSYU Muslims, is small. Religion does not influence the type of endogamous union (local versus transnational) of Turkish origin youth, whereas it does increase SSYU second generation's preference for local endogamy.

There is a distinctive pattern in educational homogamy between the two groups: youth of SSYU descent experience a higher degree of educational homogamy than the Turkish second generation. In the latter, couples' sharing ethnic origin is more important than sharing educational level. Transnational marriages seem to be linked to second generation's wish for an educated partner in both origin groups.

The main contribution of this article to the literature lies in taking into account second generation's (present personal) religion in the analysis of their marriages and putting emphasis on the religious versus ethnic boundaries. As far as future research is concerned, exploring in greater detail the role of religious boundaries on partner choices of second generation in all TIES countries will complement my analysis.

\section{References}

Alba, Richard, and Victor Nee. 2003. Remaking the American Mainstream: Assimilation and Contemporary Immigration. Cambridge: Harvard University Press.

Çelikaksoy, Aycan. 2004. Marriage Migration in Denmark. Draft paper. Denmark: Aarhus School of Business.

Erdem, Ebru. 2009. Islam, Secularism and Gender Equality: Empirical Findings from 1998 Demographic and Health Survey in Turkey. Paper presented at the American Political Science Association Annual Meeting. Toronto, Canada, September 3-6, 2009.

Fibbi, Rosita, Ceren Topgül, Dusan Ugrina, and Philippe Wanner. 2015. The New Second Generation in Switzerland: Youth of Turkish and Former Yugoslav Descent in Zurich and Basel. Amsterdam: Amsterdam University Press.

FSO (Swiss Federal Statistical Office). 2009. Les comportements démographiques des familles en Suisse. Neuchâtel: FSO.

Geaves, Ron. 2003. Religion and Ethnicity: Community Formation in the British Alevi Community. Numen 50(1): 52-70.

Girard, Alain. 1964. Le choix du conjoint. Paris: PUF, INED.

Gokalp, Catherine. 1978. Le réseau familial. Population 33(6): 1077-1094.

Gonzalez-Ferrer, Amparo. 2006. Who Do Immigrants Marry? Partner Choice among Single Immigrants in Germany. European Sociological Review 22(2): 171-185.

Hamel, Christelle, Doreen Huschek, Nadja Milewski, and Helga de Valk. 2012. Union Formation and Partner Choice. Pp. 225-284 in The European Second Generation Compared. Does the Integration Context Matter? edited by Maurice Crul, Jens Schneider, and Frans Lelie. Amsterdam: Amsterdam University Press. 
Hartung, Anne, Veronique Vandezande, Marc Swyngedouw, and Karen Phalet. 2009. Partnership Preferences of the Belgian Second Generation: Who Lives with Whom? Paper presented at the Seminar on Multi-attribute Analysis and Projection of Ethnic Populations. Jevnaker, Norway, June 3-5, 2009.

Hooghiemstra, Erna. 2003. Trouwen over de Grens. Achtergronden van Partnerkeuze van Turken en Marokkanen in Nederland. [Cross-border Marriage. Background to the Partner Choice of Turks and Moroccans in the Netherlands]. SCP-publicatie 2003/4. Den Haag: Sociaal en Cultureel Planbureau.

Kalmijn, Matthijs. 1998. Intermarriage and Homogamy: Causes, Patterns, Trends. Annual Review of Sociology 24: 395-421.

Kalter, Frank, and Julia H. Schroedter. 2010. Transnational Marriage among Former Labour Migrants in Germany. Zeitschrift für Familienforschung 22(1): 11-36.

Kennedy, Ruby Jo Reeves. 1944. Single or Triple Melting Pot? Intermarriage Trends in New Heaven 1870-1940. American Journal of Sociology 49: 331-339.

Kennedy, Ruby Jo Reeves. 1952. Single or Triple Melting Pot? Intermarriage Trends in New Heaven 1870-1950. American Journal of Sociology 58: 56-59.

Lievens, John. 1999. Family-Forming Migration from Turkey and Morocco to Belgium: The Demand for Marriage Partners from the Countries of Origin. International Migration Review 33(3): 717-744.

Lucassen, Leo, and Charlotte Laarman. 2009. Immigration, Intermarriage and the Changing Face of Europe in the Post War Period. History of the Family 14: 52-68.

Milewski, Nadja, and Christelle Hamel. 2010. Union Formation and Partner Choice in a Transnational Context: The Case of Descendants of Turkish Immigrants in France. International Migration Review 44(3): 615-658.

Sayad, Abdelmalek 1979. Les enfants illégitimes. Actes de la Recherche en Sciences Sociales 25: 61-81.

Song, Miri. 2009. Is Intermarriage a Good Indicator of Integration? Journal of Ethnic and Migration Studies 35(2): 331-348.

Strassburger, Gaby. 2004. Transnational Ties of the Second Generation: Marriages of Turks in Germany. Pp. 211-232 in Transnational Social Spaces: Agents, Networks and Institutions, edited by Thomas Faist and Eyüp Özveren. Aldershot: Ashgate.

Timmerman, Christiane. 2006. Gender Dynamics in the Context of Turkish Marriage Migration: The Case of Belgium. Turkish Studies 7(1): 125-143.

Topgül, Ceren. 2013. Partner Choice of Turkish Origin Youth in Switzerland: The Underlying Mechanisms and Social Implications for Women and Men Gender Dynamics. PhD dissertation, Demography, University of Geneva, Switzerland.

Topgül, Ceren. 2015. Family Influence on Partner Choice of Second Generation: What Are the Experiences of Turkish Origin Women in Switzerland? Pp. 43-65 in Spatial Mobility, Migration, and Family Dynamics, edited by Can Aybek, Johannes Huinink, and Raya Muttarak. Dordrecht: Springer.

Van Tubergen, Frank, and Ineke Maas. 2007. Ethnic Intermarriage among Immigrants in the Netherlands: An Analysis of Population Data. Social Science Research 36(3): 1065-1086.

Wimmer, Andreas. 2008. Elementary Strategies of Ethnic Boundary Making. Ethnic and Racial Studies 31(6): 1025-1055. 

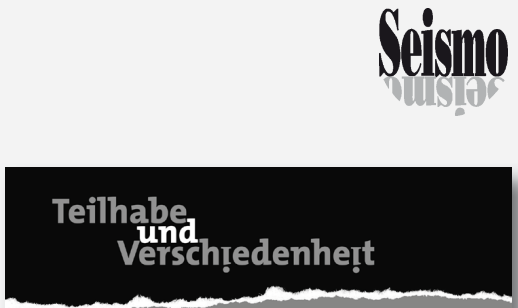

Dagmar Domenig,

und Urs Schäfer (Hrsg.)

Mediale Welt

inklusive!

Sichtbarkeit und

Teilhabe von

Menschen mit

Behinderungen

in den Medien

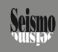

Die Beiträge in diesem Buch beleuchten die Sichtbarkeit, die Repräsentation und die Partizipation von Menschen mit Behinderungen in den Medien. Dabei liegt der Fokus einerseits auf der Darstellung von Behinderung in der Öffentlichkeit und in den Massenmedien ganz allgemein, andererseits auf den typischen kommunikativen und gestalterischen Ausprägungen in der Fotografie und im Film sowie in der Spendenwerbung von Nonprofit-Organisationen. Ein weiteres Thema dieses Buches ist der barrierefreie Zugang zum Internet für Menschen mit einer kognitiven Beeinträchtigung. Die zentrale Forderung der Beiträge ist, den Menschen mit Behinderungen ihren Platz in der medialen Welt zuzugestehen, ohne sie damit zusätzlich zu stigmatisieren, zu erniedrigen, zu verniedlichen, zu verfremden oder zu romantisieren. www.seismoverlag.ch/info@seismoverlag.ch www.editions-seismo.ch/info@editions-seismo.ch

Dagmar Domenig und Urs Schäfer (Hrsg.)

\section{Mediale Welt inklusive! Sichtbarkeit und Teilhabe von Menschen mit Behinderungen in den Medien}

\author{
Reihe \\ «Teilhabe und Verschiedenheit»
}

184 Seiten, ISBN 978-3-03777-165-5, SFr. 29.-/Euro 25.-

Die ganzseitigen Fotos stammen vom Fotografen Peter Dammann, der auch einen der Beiträge verfasst hat.

Dr. Dagmar Domenig ist Juristin, Sozialanthropologin und Pflegefachfrau. Ihre Schwerpunktthemen sind Migration und Gesundheit, transkulturelle Kompetenz, Umgang mit Verschiedenheit im Gesundheits- und Sozialwesen. Seit 2011 ist Domenig Direktorin der Stiftung Arkadis in Olten (www.arkadis.ch).

Urs Schäfer ist seit 25 Jahren im NonprofitMarketing tätig. Die ersten 10 Jahre auf Agenturseite als Kommunikationsplaner und Berater, die folgenden Jahre als Fundraiser, Marketing- und Kommunikationsleiter bei diversen Nonprofit-Organisationen; aktuell bei der Stiftung Arkadis in Olten. 